\title{
Phytochemistry of Trattinnickia burserifolia, T. rhoifolia, and Dacryodes hopkinsii: Chemosystematic Implications
}

\author{
M. da Paz Lima ${ }^{a}$, Patrícia A. de Campos Braga ${ }^{b}$, Mario Lopes Macedo ${ }^{b}$, M. Fátima das G. F. da \\ Silva ${ }^{*, b}$, A. Gilberto Ferreira ${ }^{b}$,João B. Fernandes ${ }^{b}$ and Paulo C. Vieira ${ }^{b}$ \\ ${ }^{a}$ Instituto Nacional de Pesquisa da Amazônia, Coordenação de Pesquisas em Produtos Naturais, \\ CP 478, 69011-970 Manaus - AM, Brazil \\ ${ }^{b}$ Departamento de Química, Universidade Federal de São Carlos, CP 676, 13565-905 São Carlos - SP, Brazil
}

\begin{abstract}
O estudo de Trattinnickia burserifolia levou ao isolamento dos triterpenos conhecidos ursanos $\alpha$-amirenona, $\alpha$-amirina, 3-epi- $\alpha$-amirina, $3 \alpha, 16 \beta$-diidroxiurs-12-eno; oleananos $\beta$-amirenona, $\beta$ amirina, 3-epi- $\beta$-amirina, $3 \alpha, 16 \beta$-diidroxiolean-12-eno; tirucalanos ácidos $3 \alpha$-hidroxitirucal-8,24dien-21-óico, $3 \alpha$-hidroxitirucal-7,24-dien-21-óico, e 3-oxotirucal-8,24-dien-21-óico; damaranos dammarenediol-II e $3 \alpha, 20(\mathrm{~S})$-diidroxidamar-24-eno. Além desses foram ainda isolados o monoterpeno novo $2\left(\mathrm{~S}^{*}\right)$-fenilacetoxi-4( $\left.\mathrm{R}^{*}\right)$-p-menta-1(7),5-dieno, e os triterpenos novos $3 \beta$ fenilacetoxiurs-12-eno, $3 \beta$-fenilacetoxiolean-12-eno e $3 \beta, 16 \beta, 11 \alpha$-triidroxiurs-12-eno. Os triterpenos de T. burserifolia, T. rhoifolia e Dacryodes foram analisados em mistura. Os espectros de RMN ${ }^{13} \mathrm{C}$ mostraram que os principais triterpenos eram $\alpha$-amirina e $\beta$-amirina em T. burserifolia $; \alpha$-amirina, $\beta$ amirina, 3-epi- $\alpha$-amirina, 3-epi- $\beta$-amirina, lupenona, ácidos $3 \alpha$-hidroxitirucal-8,24-dien-21-óico e $3 \alpha$-hidroxitirucal-7,24-dien-21-óico em T. rhoifolia; $\alpha$-amirina, $\beta$-amirina, lupeol, tirucalol, sitosterol e estigmasterol em $D$. hopkinsii. A quimiossistemática da tribo Protieae é discutida.
\end{abstract}

Trattinnickia burserifolia has yielded the known ursanes, $\alpha$-amyrenone, $\alpha$-amyrin, 3-epi- $\alpha$ amyrin, $3 \alpha, 16 \beta$-dihydroxyurs-12-ene, the oleananes $\beta$-amyrenone, $\beta$-amyrin, 3 -epi- $\beta$-amyrin, $3 \alpha, 16 \beta$-dihydroxyolean-12-ene, the tirucallane acids $3 \alpha$-hydroxytirucall-8,24-dien-21-oic, $3 \alpha$ hydroxytirucall-7,24-dien-21-oic and 3-oxotirucall-8,24-dien-21-oic, the dammaranes dammarenediol-II and $3 \alpha, 20(\mathrm{~S})$-dihydroxydammar-24-ene. Besides it was isolated the new monoterpene $2\left(\mathrm{~S}^{*}\right)$-phenylacetoxy-4(R*)-p-mentha-1(7),5-diene and, the new triterpenes $3 \beta$ phenylacetoxyurs-12-ene, $3 \beta$-phenylacetoxyolean-12-ene and $3 \beta, 16 \beta, 11 \alpha$-trihydroxyurs-12-ene. The triterpenes from T. burserifolia, T. rhoifolia and Dacryodes were analyzed in mixture. Their ${ }^{13} \mathrm{C}$ NMR spectra showed that the major triterpenes were in T. burserifolia $\alpha$-amyrin and $\beta$-amyrin; in $T$. rhoifolia $\alpha$-amyrin, $\beta$-amyrin, 3-epi- $\alpha$-amyrin, 3-epi- $\beta$-amyrin, and lupenone; in T. rhoifolia $\alpha$ amyrin, $\beta$-amyrin, 3-epi- $\alpha$-amyrin, 3-epi- $\beta$-amyrin, $3 \alpha$-hydroxytirucall-8,24-dien-21-oic acid and $3 \alpha$-hydroxytirucall-7,24-dien-21-oic acid; in D. hopkinsii $\alpha$-amyrin, $\beta$-amyrin, lupeol, tirucallol, sitosterol and stigmasterol. Aspects of chemosystematic of the tribe Protieae are discussed.

Keywords: Burseraceae, monoterpene, triterpenes, chemosystematic

\section{Introduction}

The Burseraceae has usually been considered to contain 21 genera and nearly 600 species. Engler (1931) classified these genera into three tribes. ${ }^{1}$ The Protieae consist of four genera exhibiting many morphological characters regarded as primitives. Three Protieae genera occur in tropical America and one in Asia. The following group the Boswellieae contain eight genera centred in

* e-mail: dmfs@power.ufscar.br
Africa and Asia. In contrast, the Canarieae, represented by nine genera, appear more advanced in their morphology. This tribe is predominantly Paleotropical, therefore, two genera occur in South America. Later Lam (1932) recognised these tribes but replaced the name Boswellieae by Bursereae. ${ }^{2}$

Crepidospermum Hook. is a member of the Protieae and consists of five species distributed in the tropical South America. Swart in 1942 on morphological grounds described the genus Hemicrepidospermum to accommodate $C$. rhoifolium. ${ }^{3}$ However, other aspects of 
their morphology have led Daly (1989) to consider Hemicrepidospermum a section of Crepidospermum; the two sections have three and two species, respectively. ${ }^{4}$ The following tropical S. American genera of the Protieae, Tetragastris and Protium, have long been considered closely related, in fact, many specimens of each genus have been mistakenly referred to the other. ${ }^{4}$ Garuga is the only representative of Asian Protieae and its morphology is easily recognisable. ${ }^{4}$

Trattinnickia was also a member of the Protieae, however, morphological and anatomical evidence have led Daly (1989) to transfer it into the Canarieae and to propose a taxonomic position close to Dacryodes. ${ }^{4}$

Within tribe Protieae phytochemical data were not available for Crepidospermam, Tetragastris, Trattinnickia and Dacryodes. As part of our chemosystematic interest in the Brazilian Burseraceae, we recently reported the phytochemical investigation of Crepidospermam rhoifolium Benth. and Tetragastris altissima (Aublet) Swart. ${ }^{5}$ Thus, we have now examined the resin, stem bark and branches of Trattinnickia burserifolia Engl., T. rhoifolia var. willdenowii Engl. and Dacryodes hopkinsii Daly. ${ }^{4}$

\section{Resulsts and Discussion}

\section{Chemical composition of the extracts}

A chloroform-soluble fraction of the resin of $T$. burserifolia afforded one new monoterpene (1), three new triterpenes (2-4) and the known ursanes, $\alpha$-amyrenone, ${ }^{6} \alpha$ amyrin (5), 3-epi- $\alpha$-amyrin, $3 \alpha, 16 \beta$-dihydroxyurs-12-ene
(6), ${ }^{7}$ the oleananes $\beta$-amyrenone, ${ }^{6} \beta$-amyrin (7), 3-epi- $\beta$ amyrin, $3 \alpha, 16 \beta$-dihydroxyolean-12-ene $(8),{ }^{7}$ the tirucallane acids $3 \alpha$-hydroxytirucall-8,24-dien-21-oic, ${ }^{8}$ $3 \alpha$-hydroxytirucall-7,24-dien-21-oic, ${ }^{6} 3$-oxotirucall-8,24dien-21-oic, ${ }^{8}$ and the dammaranes dammarenediol-II and $3 \alpha, 20$ (S)-dihydroxydammar-24-ene. ${ }^{5}$

The ${ }^{1} \mathrm{H}$ NMR spectrum (Table 1 ) of compound $\mathbf{1}$ showed signals for a terminal methylene $(\delta 5.08$, br s, and 5.00 , br s), two olefinic protons which were coupled to each other $(\delta 5.80$, dd, $J 10.1$ and $1.0 \mathrm{~Hz} ; 6.14$, dd, $J 10.1$ and $2.5 \mathrm{~Hz}$ ), two methyl doublet $(\delta 0.88, \mathrm{~d}, J 6.8 \mathrm{~Hz} ; 0.86, \mathrm{~d}, J 6.8 \mathrm{~Hz})$, an oxymethine $(\delta 5.57$, dd, $J 5.0$ and $2.8 \mathrm{~Hz})$, an aryl substituted methylene $(\delta 3.61,2 \mathrm{H}, \mathrm{s})$ and five protons as a multiplet between $\delta 7.30$ and 7.25, clearly indicating the presence of a phenyl group. From HMBC experiments the observed correlations between the methylene protons at $\delta$ 5.08 and 5.00 and the ${ }^{13} \mathrm{C}$ signals at $\delta 127.2$ and 71.8, requiring the presence of a conjugated double bond and an allylic proton attached to a carbon adjacent to an oxygen atom. HSQC experiments showed correlations of terminal methylene and conjugated double bond protons $(\delta 5.80$ and 6.14) with the ${ }^{13} \mathrm{C}$ signals at $\delta 115.4,133.7$ and 127.2, respectively. HSQC also permitted the assignment of the signal at $\delta 41.8$ to aryl substituted methylene at $\delta 3.61$, which showed cross peaks with the ${ }^{13} \mathrm{C}$ signals of the aromatic ring (C-1', C-2' and C-6') and carboxyl at $\delta$ 171.1, indicating a phenylacetoxyl substituent. This group must be connected allylic to terminal methylene, due to the observed downfield shifted proton signal at $\delta 5.57$, which showed one-bond correlation with the ${ }^{13} \mathrm{C}$ signal at $\delta 71.8$. These correlations resulted in the construction of a $\mathrm{CH}_{2}=\mathrm{C}\left[\mathrm{CH}(\mathrm{R}) \mathrm{OCOCH}_{2} \mathrm{Ph}\right] \mathrm{CH}=\mathrm{CHR}$ system.

Table 1. ${ }^{13} \mathrm{C}$ and ${ }^{1} \mathrm{H}$ NMR spectral data for compounds $\mathbf{1}$ and the model compounds $\mathbf{9}$ and $\mathbf{1 0}$

\begin{tabular}{|c|c|c|c|c|c|c|c|}
\hline $\mathrm{C}$ & 1 & 9 & 10 & $\mathrm{H}$ & $1(2 S)$ & $9(2 S)$ & $10(2 R)$ \\
\hline 1 & 140.5 & 139.4 & 141.7 & $\mathrm{OOH}$ & & $7.73 \mathrm{~s}$ & $7.87 \mathrm{~s}$ \\
\hline \multirow[t]{2}{*}{2} & 71.8 & 82.6 & 82.5 & 2 & $5.57 \mathrm{dd}(5.0,2.8)$ & $4.67 \mathrm{dd}(3.5,3.0)$ & $4.68 \mathrm{dm}(11.0)$ \\
\hline & & & & $3 \mathrm{a}$ & $1.89 \mathrm{dt}(13.6,5.0)$ & $2.17 \mathrm{dtd}(13.7,4.9,3.5,1.4)$ & $2.22 \mathrm{dt}(11.0,4.2)$ \\
\hline 3 & 30.4 & 29.0 & 30.1 & $3 b$ & 1.55 ddd $(13.6,9.8,2.8)$ & 1.57 td $(13.7,11.5,3.0)$ & $1.63 \mathrm{q}(11.0)$ \\
\hline 4 & 37.8 & 36.9 & 42.0 & 4 & $2.20 \mathrm{~m}$ & $2.26 \mathrm{~m}$ & $2.25 \mathrm{~m}$ \\
\hline 5 & 133.7 & 134.1 & 133.3 & 5 & $5.80 \mathrm{dd}(10.1,1.0)$ & $5.80 \mathrm{~d}(10.0)$ & $5.71 \mathrm{~d}(9.7)$ \\
\hline 6 & 127.2 & 126.7 & 128.6 & 6 & $6.14 \mathrm{dd}(10.1,2.5)$ & $6.13 \mathrm{dd}(10.0,2.5)$ & $6.13 \mathrm{dd}(9.7,2.4)$ \\
\hline 7 & 115.4 & 116.7 & 109.9 & $7 \mathrm{a}$ & 5.08 br s & $5.15 \mathrm{~s}$ & $5.17 \mathrm{~s}$ \\
\hline 8 & 31.4 & 31.4 & 31.9 & $7_{\mathrm{b}}^{\mathrm{a}}$ & $5.00 \mathrm{br} \mathrm{s}$ & $5.13 \mathrm{~s}$ & $4.98 \mathrm{~s}$ \\
\hline 9 & 19.5 & 19.2 & 19.6 & 8 & $1.60 \mathrm{~m}$ & 1.69 sept.d $(6.8,5.5)$ & 1.74 sept.d $(6.8,5.2)$ \\
\hline 10 & 19.4 & 19.2 & 19.2 & 9 & $0.88 \mathrm{~d}(6.8)$ & $0.90 \mathrm{~d}(6.8)$ & $0.94 \mathrm{~d}(6.8)$ \\
\hline 1 , & 134.3 & & & 10 & $0.86 \mathrm{~d}(6.8)$ & $0.90 \mathrm{~d}(6.8)$ & $0.92 \mathrm{~d}(6.8)$ \\
\hline $2^{\prime} / 6^{\prime}$ & 129.3 & & & $2^{\prime}-6^{\prime}$ & $7.25-7.30 \mathrm{~m}$ & & \\
\hline $3^{\prime} / 5$ & 128.5 & & & 7 & $3.61 \mathrm{~s}$ & & \\
\hline $4^{\prime}$ & 127.0 & & & & & & \\
\hline 7 , & 41.8 & & & & & & \\
\hline 8 & 171.1 & & & & & & \\
\hline
\end{tabular}

Assignments based on HSQC and HMBC for $\mathbf{1}$. 
<smiles>O=C(Cc1ccccc1)OC1CC(C(=O)O)C=CC1=O</smiles>

1

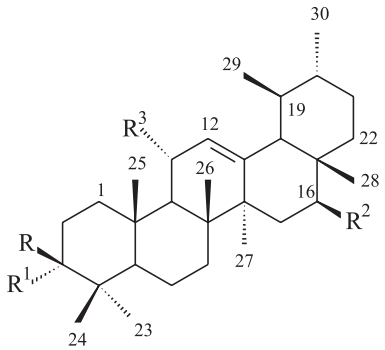

2: $\mathrm{R}=\mathrm{OCOCH}_{2} \mathrm{Ph}$;

$\mathrm{R}^{1}, \mathrm{R}^{2}, \mathrm{R}^{3}=\mathrm{H}$

4: $\mathrm{R}, \mathrm{R}^{2}, \mathrm{R}^{3}=\mathrm{OH} ; \mathrm{R}^{1}=\mathrm{H}$

5: $\mathrm{R}=\mathrm{OH} ; \mathrm{R}^{1}, \mathrm{R}^{2}, \mathrm{R}^{3}=\mathrm{H}$

6: $\mathrm{R}^{1}, \mathrm{R}^{2}=\mathrm{OH} ; \mathrm{R}, \mathrm{R}^{3}=\mathrm{H}$

6a: $R^{1}, R^{2}=O A c ; R, R^{3}=H$

11: $\mathrm{R}, \mathrm{R}^{2}=\mathrm{OH} ; \mathrm{R}^{1}, \mathrm{R}^{3}=\mathrm{H}$

12: $\mathrm{R}^{1}, \mathrm{R}^{3}=\mathrm{OH} ; \mathrm{R}, \mathrm{R}^{2}=\mathrm{H}$

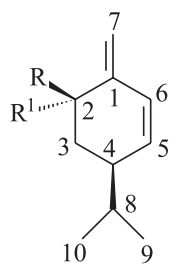

9: $\mathrm{R}=\mathrm{H}, \mathrm{R}^{1}=\mathrm{OOH}$ 10: $\mathrm{R}=\mathrm{OOH}, \mathrm{R}^{1}=\mathrm{H}$

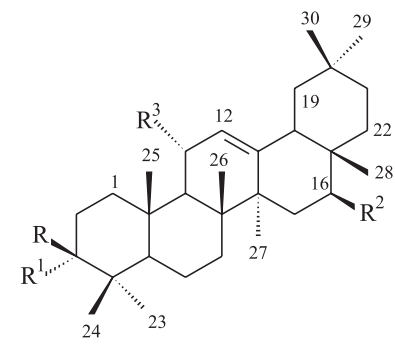

3: $\mathrm{R}=\mathrm{OCOCH}_{2} \mathrm{Ph}$, $\mathrm{R}^{1}, \mathrm{R}^{2}, \mathrm{R}^{3}=\mathrm{H}$ 7: $\mathrm{R}=\mathrm{OH}, \mathrm{R}^{1}, \mathrm{R}^{2}, \mathrm{R}^{3}=\mathrm{H}$ 8: $\mathrm{R}^{1}, \mathrm{R}^{2}=\mathrm{OH} ; \mathrm{R}, \mathrm{R}^{3}=\mathrm{H}$ 8a: $R^{1}, R^{2}=$ OAc; $R, R^{3}=H$

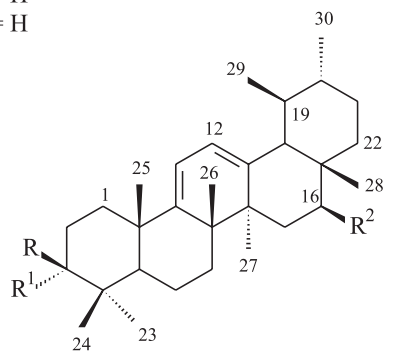

4a: $\mathrm{R}, \mathrm{R}^{2}=\mathrm{OAc} ; \mathrm{R}^{1}=\mathrm{H}$

13: $R=O A c ; R^{2}, R^{1}=H$

The remaining unassigned ${ }^{13} \mathrm{C}$ signals accounted for 2 $\mathrm{CH}_{3}, \mathrm{CH}_{2}$ and $2 \mathrm{CH}$, of which two methyls were coupled to a methine, suggesting the presence of a monoterpene $p$ menthane skeleton to be substituted with phenylacetoxyl. The identification of the nucleus as a $p$-menthane was supported by comparison of the ${ }^{13} \mathrm{C}$ NMR spectrum (Table 1) with those of $2(\mathrm{~S})$-hydroperoxy-4(R)-p-mentha-1(7),5diene (9) and 2(R)-hydroperoxy-4(R)-p-mentha-1(7),5diene (10) obtained from photooxygenation of (-)-(R)- $\alpha$ phellandrene. ${ }^{9}$ Based on the ${ }^{1} \mathrm{H}$ and ${ }^{13} \mathrm{C}$ NMR data for 9 and 10, in compound 1 the resonances for $\mathrm{H}-2(\delta 5.57$, dd, $J 5.0$ and $2.8 \mathrm{~Hz})$ and C-4 $(\delta 37.8)$ were characteristic of $2(\mathrm{~S})-4(\mathrm{R})-p$-menthane derivative, but this has not been confirmed. Compound $\mathbf{1}$ is thus $2\left(\mathrm{~S}^{*}\right)$-phenylacetoxy$4\left(\mathrm{R}^{*}\right)$ - $p$-mentha-1(7),5-diene.

The two new triterpenes $\mathbf{2}$ and $\mathbf{3}$ showed a single spot on TLC in various solvent systems and attempts to separate this mixture into its constituents were not successful. They also showed the spectral characteristics of a phenylacetoxyl substituent. The ${ }^{1} \mathrm{H}$ and ${ }^{13} \mathrm{C}$ NMR spectra of this mixture in addition to signals described above for phenylacetoxyl, revealed resonances for $\mathrm{C}-1$ and $\mathrm{H}-1$ to $\mathrm{C}-30$ and $\mathrm{H}-30$ in close agreement with those for $\alpha$-amyrin (5) and $\beta$-amyrin (7), respectively ${ }^{7}, 10$ (Table 2 ). The downfield shift of the signals for C-3 $(\delta 81.4)$ and $\mathrm{H}-3(\delta 4.48)$ in the ${ }^{1} \mathrm{H}$ and ${ }^{13} \mathrm{C}$ NMR spectra, when compared with $\mathbf{5}$ and 7, determined the position of the phenylacetoxyl at C-3 in both the compounds of the mixture. The phenylacetoxyl present at $\mathrm{C}-3 \beta$ was evident by resonance at $\delta 4.48$ with a large coupling constant $(J 11.0$ and $5.1 \mathrm{~Hz})$. The structure of the new natural products were thus established as $3 \beta$ phenylacetoxyurs-12-ene (2) and $3 \beta$-phenylacetoxyolean12-ene (3).

Table 2. ${ }^{13} \mathrm{C}$ NMR spectrum data for compounds 2,3 and the model compounds 5 and 7

\begin{tabular}{rrrrrrrr}
\hline C & \multicolumn{1}{c}{$\mathbf{2}$} & \multicolumn{1}{c}{$\mathbf{3}$} & \multicolumn{1}{c}{$\mathbf{5}$} & \multicolumn{1}{c}{$\mathbf{7}$} & \multicolumn{1}{c}{ C } & \multicolumn{1}{c}{$\mathbf{2}$} & \multicolumn{1}{c}{$\mathbf{c}$} \\
\hline 1 & 38.5 & 38.4 & 38.7 & 38.7 & 1 & 134.5 & 134.5 \\
2 & 27.9 & 27.0 & 27.2 & 27.3 & 2 & 129.3 & 129.3 \\
3 & 81.4 & 81.4 & 78.3 & 79.0 & 3 & 128.5 & 128.5 \\
4 & 37.8 & 37.8 & 38.7 & 38.8 & 4 & 126.9 & 126.9 \\
5 & 55.3 & 55.3 & 55.2 & 55.3 & 5, & 128.5 & 128.5 \\
6 & 18.2 & 18.2 & 18.3 & 18.5 & 6 & 129.3 & 129.3 \\
7 & 32.5 & 32.5 & 32.9 & 32.8 & 7 & 42.1 & 42.1 \\
8 & 40.1 & 40.1 & 40.0 & 38.8 & 8 & 171.3 & 171.3 \\
9 & 47.7 & 47.6 & 47.7 & 47.7 & & & \\
10 & 36.8 & 36.8 & 36.9 & 37.6 & & & \\
11 & 23.4 & 23.7 & 23.3 & 23.6 & & & \\
12 & 124.4 & 121.7 & 124.3 & 121.8 & & & \\
13 & 139.7 & 145.0 & 139.3 & 145.1 & & & \\
14 & 42.1 & 41.8 & 42.0 & 41.8 & & & \\
15 & 27.9 & 26.2 & 28.7 & 26.2 & & & \\
16 & 26.6 & 25.9 & 26.6 & 27.0 & & & \\
17 & 32.9 & 32.8 & 33.7 & 32.5 & & & \\
18 & 59.1 & 47.3 & 58.9 & 47.4 & & & \\
19 & 39.7 & 46.8 & 39.6 & 46.9 & & & \\
20 & 39.6 & 31.1 & 39.6 & 31.1 & & & \\
21 & 31.3 & 34.8 & 31.2 & 34.8 & & & \\
22 & 41.6 & 37.3 & 41.5 & 37.2 & & & \\
23 & 28.1 & 28.1 & 28.1 & 28.2 & & & \\
24 & 15.7 & 15.5 & 15.6 & 15.5 & & & \\
25 & 16.8 & 16.6 & 15.6 & 15.6 & & & \\
26 & 16.9 & 16.8 & 16.8 & 16.9 & & & \\
27 & 23.3 & 25.9 & 23.3 & 26.0 & & & \\
28 & 28.8 & 28.4 & 28.1 & 28.4 & & & \\
29 & 17.5 & 33.8 & 17.4 & 33.3 & & & \\
30 & 21.4 & 23.7 & 21.3 & 23.7 & & & \\
\hline & & & & & & & \\
& & &
\end{tabular}

The new triterpene $\mathbf{4}$ was identified on the basis of the following data. The ${ }^{1} \mathrm{H}$ NMR spectrum indicated the presence of three signals characteristics of protons attached to a carbon adjacent to an oxygen atom $(\delta 3.23$, dd, $J 10.4$ and $5.8 \mathrm{~Hz}$; 4.23, dd, $J 11.1$ and $5.2 \mathrm{~Hz}$; 4.27, dd, $J 8.7$ and $3.2 \mathrm{~Hz})$, one olefinic proton $(\delta 5.24, \mathrm{~d}, J 3.2 \mathrm{~Hz})$, and eight 
methyl groups, six of them on quaternary carbons and two of them on a methine group, suggesting a urs-12-ene skeleton. From the HMBC experiments (Table 3) the observed correlations between the two methyl protons at $\delta 0.77$ and 0.97 and the ${ }^{13} \mathrm{C}$ signals at $\delta 78.7\left({ }^{3} \mathrm{~J} ; \mathrm{CH}\right.$ by DEPT), 55.4 ( ${ }^{3} \mathrm{~J}$; CH), 39.3 ( ${ }^{2} \mathrm{~J}$; quaternary carbon), 28.4 ( ${ }^{3} \mathrm{~J}$ for methyl at $\delta 0.97 ; \mathrm{CH}_{3}$ ) and 15.7 ( $3 J$ for methyl at $\delta 0.77$; $\mathrm{CH}_{3}$ ) led to their assignments as C-3, C-5, C-4, C-23 and $\mathrm{C}-24$, respectively. Based on the HSQC experiments the signal at $\delta 0.77,0.97$ and 3.23 were then assigned to Me$24, \mathrm{Me}-23$ and $\mathrm{H}-3$, respectively. The methyl proton at $\delta$ $1.06\left(\delta_{\mathrm{C}} 17.0\right)$ showed long-range correlation with the ${ }^{13} \mathrm{C}$ signal for C-5 ( $\delta 55.4)$, permitting the assignment of these signals to $\mathrm{H}_{3}-25$ and $\mathrm{C}-25$, respectively. The signal for $\mathrm{H}_{3}-$ 25 also showed correlations with the ${ }^{13} \mathrm{C}$ signals at 55.3 $(\mathrm{CH}), 40.9\left(\mathrm{CH}_{2}\right)$ and 38.1 (quaternary carbon), showing that these signals correspond to C-9, C-1 and C-10, respectively. The olefinic proton at $\delta 5.24$ showed cross peaks with the C-9 signal ( $\delta 55.3)$, and was coupled to the ${ }^{1} \mathrm{H}$ signal at $\delta 4.27$, thus indicating a hydroxyl group to be located at $\mathrm{C}-11$ and a double bond at $\mathrm{C}-12$. The late oxymethine proton showed one-bond correlation with the ${ }^{13} \mathrm{C}$ signal at $\delta 68.2$ and long-range correlation with the ${ }^{13} \mathrm{C}$ signals at $\delta 141.3$ and 129.2 , allowing the assignment of these to $\mathrm{C}-11, \mathrm{C}-13$ and $\mathrm{C}-12$, respectively. Moreover, the existence of correlations between $\mathrm{H}-12$ and the ${ }^{13} \mathrm{C}$

Table 3. HMBC assignments for $\mathbf{4}$ and $\mathbf{4 a}$, and G-NOESY for $\mathbf{4}$

\begin{tabular}{clll}
\hline \multicolumn{2}{c}{ 4 HMBC } & \multicolumn{2}{c}{ 4a HMBC } \\
\hline $\mathrm{H}$ & $\mathrm{C}$ & $\mathrm{H}$ & $\mathrm{C}$ \\
\hline 3 & 24 & 3 & Ac $(170.0), 23,24$ \\
9 & $5,8,10,11,26,25$ & & \\
11 & 12,13 & 11 & $8,10,13$ \\
12 & $9,14,18$ & 12 & $9,14,18$ \\
15 & $13,16,17$ & & \\
16 & 28 & 16 & Ac $(169.8), 28$ \\
18 & $12,13,14,16,17,19$ (or 20) & 18 & $12,13,14,17$ \\
23 & $3,4,5,24$ & 23 & $3,4,5,24$ \\
24 & $3,4,5,23$ & 24 & $3,5,23$ \\
25 & $1,5,9,10$ & 25 & $1,5,9,10$ \\
26 & $7,8,9,14$ & 26 & $7,8,14$ \\
27 & $8,13,14,15$ & 27 & $8,13,14,15$ \\
28 & $16,17,18,22$ & 28 & $16,17,18,22$ \\
29 & 18,19 (or 20) & 29 & $18,19,20$ \\
30 & 19 (or 20),21 & 30 & $19,20,21$
\end{tabular}

signals at $\delta 59.9(\mathrm{CH})$ and 44.3 (quaternary carbon) led to their assignments as $\mathrm{C}-18$ and $\mathrm{C}-14$, respectively. A fourth methyl proton at $\delta 1.20\left(\delta_{\mathrm{C}} 24.3\right)$ was attributed to $\mathrm{H}_{3}-27$ by its correlations with the C-13 $(\delta$ 141.3) and C-14 $(\delta$ $44.3)$ signals. The $\mathrm{H}_{3}-27$ signal also showed a cross-peak with the signal at $\delta 43.6$, confirming a methyl group at $\mathrm{C}$ 8 . In the same way, the unsubstituted $\mathrm{C}-15$ emerged from the correlation between the $\mathrm{H}_{3}-27$ signal and the ${ }^{13} \mathrm{C}$ signal at $\delta 36.0\left({ }^{3} \mathrm{~J} ; \mathrm{CH}_{2}\right)$, which showed one-bond correlation with the ${ }^{1} \mathrm{H}$ signal at $\delta 1.36(\mathrm{~m})$. This signal was coupled to the ${ }^{1} \mathrm{H}$ signal at $\delta 4.23(\mathrm{dd}, J 11.1$ and $5.2 \mathrm{~Hz}$ ), requiring the presence of a hydroxyl function at C-16. The coupling constants indicated that the hydroxyl group was attached $\beta$ (equatorial) to $\mathrm{C}-16$ and was coupled only to $\mathrm{H}_{2}-15$, indicating $\mathrm{C}-17$ fully substituted. This was supported by the relationship of the $\mathrm{H}-16(\delta 4.23)$ signal to the ${ }^{13} \mathrm{C}$ signal at $\delta$ 21.9, which showed one-bond correlation with the methyl proton at $\delta 0.73$, and long-range correlation with the ${ }^{13} \mathrm{C}$ signals for $\mathrm{C}-18, \mathrm{C}-16$ and at $\delta 38.5$ (quaternary carbon) and $35.2\left(\mathrm{CH}_{2}\right)$. The signals at $\delta_{\mathrm{H}} 0.73, \delta_{C} 21.9$, 38.5 and 35.2 were then assigned to $\mathrm{H}_{3}-28, \mathrm{C}-28, \mathrm{C}-17$ and C-22, respectively. A sixth methyl proton at $\delta 1.05(\delta 18.0)$ was attributed to $\mathrm{H}_{3}-26$ by its correlation with the $\mathrm{C}-9$ and $\mathrm{C}-14 . \mathrm{H}_{3}-26$ signal also showed cross peaks with the ${ }^{13} \mathrm{C}$ signal at $\delta 43.6$ (quaternary carbon) and $33.7\left(\mathrm{CH}_{2}\right)$, which were attributed to $\mathrm{C}-8$ and $\mathrm{C}-7$, respectively. A seventh methyl proton at $\delta_{\mathrm{H}} 0.82\left(\mathrm{~d}, J 6.3 \mathrm{~Hz} ; \delta_{\mathrm{C}} 17.8\right)$ was attributed to $\mathrm{H}_{3}-29$ by its correlation with the $\mathrm{C}-18$ signal. $\mathrm{H}_{3}-29$ signal also showed cross peaks with the ${ }^{13} \mathrm{C}$ signal at $\delta 39.1(\mathrm{CH})$ and (or) $39.5(\mathrm{CH})$, suggesting a methine for C-20, indicating a methyl group to be located at C-20 and confirming a urs-12-ene skeleton. Thus, the eighth methyl proton at $\delta_{\mathrm{H}} 0.91\left(\mathrm{~d}, J 5.9 \mathrm{~Hz} ; \delta_{\mathrm{C}} 21.5\right)$ was attributed to $\mathrm{H}_{3}-30$. The signal for $\mathrm{C}-21$ was established as $\delta 30.4\left(\mathrm{CH}_{2}\right.$; $\delta_{\mathrm{H}} 1.42 \mathrm{~m}$, by HSQC) by the existence of a correlation between the $\mathrm{H}_{3}-30$ signal and this ${ }^{13} \mathrm{C}$ signal.

The stereochemistry suggested for $\mathbf{4}$ was based on the biosynthesis of urs-12-enes. However, for C-3, C-11 and $\mathrm{C}-16$ the stereochemistry were assigned by coupling constants and NOESY experiments. A model shows that, in compound 4, ring $\mathrm{A}$ is nearer to a chair conformation, in which $\mathrm{H}-3$ and $\mathrm{H}-5$ are on the $\alpha$-side of the molecule. This was supported by NOESY experiments (Table 3 ), which showed correlation of the signal of $\mathrm{H}-3 \alpha(\delta 3.23$; OH-3 $\beta$ ) with the signal of $\mathrm{H}-5 \alpha(\delta 0.72 \mathrm{~m}$, by HSQC). Moreover, the existence of a correlation from $\mathrm{H}-3$ to $\mathrm{H}_{3}-23(\delta 0.97)$ confirmed that Me-23 is in the $\alpha$-configuration. In addition, the signal of H-11 ( $\delta 4.27)$ showed cross-peaks with the signals of $\mathrm{H}_{3}-25(\delta 1.06)$ and $\mathrm{H}_{3}-26(\delta 1.05)$, suggesting a spatial proximity of $\mathrm{H}-11$ to Me-25 and Me-26, which requires $11-\mathrm{OH}$ to be in the $\alpha$-configuration. The 
relationship of $\mathrm{H}-16$ signal $(\delta 4.23)$ to the $\mathrm{H}_{3}-27(\alpha, \delta 1.20)$ indicated that $16-\mathrm{OH}$ is in the $\beta$-configuration.

The ESI-MSMS showed ions at $\mathrm{m} / z 457[\mathrm{M}-\mathrm{H}], 439$ $\left[\mathrm{M}-\mathrm{H}-\mathrm{H}_{2} \mathrm{O}\right]^{-}$and $421\left[\mathrm{M}-\mathrm{H}-\mathrm{H}_{2} \mathrm{O}-\mathrm{H}_{2} \mathrm{O}\right]^{-}$, confirming the presence of hydroxyl groups and thus the molecular formula $\left(\mathrm{C}_{30} \mathrm{H}_{50} \mathrm{O}_{3}\right)$. Based in the above evidence the structure of this compound was thus established as $3 \beta, 16 \beta, 11 \alpha$-trihydroxyurs-12-ene (4). The structural assignment was also supported by comparison of the ${ }^{13} \mathrm{C}$ NMR spectrum (Table 4) with those of $3 \beta, 16 \beta$ dihydroxyurs-12-ene (11) ${ }^{7}$ and $3 \alpha, 11 \alpha$-dihydroxyurs-12ene (12). ${ }^{10}$ In order to confirm of the assignments for $\mathbf{6 a}$ and $\mathbf{8 a}$ discussed below, $\mathbf{4}$ was acetylated. This reaction involved dehydration of $\mathrm{C}-11$ alcohol and acetylation of the $\mathrm{C}-3$ and $\mathrm{C}-16$ hydroxyl groups to give $3 \beta, 16 \beta$ diacetoxyurs-9(11),12-diene (4a). The ${ }^{1} \mathrm{H}$ NMR spectrum of 4a revealed the downfield shift of the signals for $\mathrm{H}-3$ ( $\delta$ 4.51 , dd, $J 11.4$ and $4.9 \mathrm{~Hz})$ and $\mathrm{H}-16(\delta 5.46$, dd, $J 11.4$ and $5.5 \mathrm{~Hz}$ ). From the HMBC experiments (Table 3) the observed correlations between the two methyl protons at $\delta 0.88$ and 0.90 and the ${ }^{13} \mathrm{C}$ signals at $\delta 79.5,50.0\left({ }^{3} \mathrm{~J} ; \mathrm{CH}\right)$, $36.8\left({ }^{2} J\right.$; quaternary carbon), $27.1\left({ }^{3} J, \mathrm{CH}_{3}\right)$ and $15.7\left({ }^{3} \mathrm{~J}\right.$, $\mathrm{CH}_{3}$ ) led to their assignments as $\mathrm{C}-3, \mathrm{C}-5, \mathrm{C}-4, \mathrm{C}-23$ and $\mathrm{C}-24$, respectively. The oxymethine proton at $\delta 4.51$ showed long-range correlation with the ${ }^{13} \mathrm{C}$ signal at $\delta$ 170.0 and with the $\mathrm{C}-24(\delta 15.7)$ and $\mathrm{C}-23(\delta 27.1)$ signals, confirming this proton signal to $\mathrm{H}-3$ and allowing the assignment of the signal at $\delta 170.0$ to $\mathrm{C}-3$ acetoxyl group. Moreover, the existence of correlations between $\mathrm{H}_{3}-28(\delta$ $0.91)$ and the ${ }^{13} \mathrm{C}$ signals at $\delta 69.9(\mathrm{CH}), 57.8(\mathrm{CH}), 36.3$ (quaternary carbon) and $34.4\left(\mathrm{CH}_{2}\right)$ led to their assignments as $\mathrm{C}-16, \mathrm{C}-18, \mathrm{C}-17$ and $\mathrm{C}-22$, respectively. Thus, the

Table 4. ${ }^{13} \mathrm{C}$ NMR spectrum data for compounds $\mathbf{4}, \mathbf{4 a}, \mathbf{6 a}, \mathbf{8 a}$, and the model compounds $\mathbf{6}, \mathbf{8}, \mathbf{1 1}, \mathbf{1 2}$ and $\mathbf{1 3}{ }^{10,26-29}$

\begin{tabular}{|c|c|c|c|c|c|c|c|c|c|}
\hline $\mathrm{C}$ & 4 & 11 & 12 & $4 a^{b}$ & 13 & 6 & $6 a$ & 8 & $8 \mathbf{a}$ \\
\hline 1 & 40.9 & 38.7 & 33.5 & 35.9 & 37.0 & 33.3 & 32.6 & 33.1 & 32.4 \\
\hline 2 & 27.4 & 27.2 & 25.4 & 23.1 & 24.3 & 25.2 & 22.7 & 25.2 & 22.7 \\
\hline 3 & 78.7 & 78.9 & 76.0 & 79.5 & 80.6 & 76.1 & 78.1 & 76.1 & 78.1 \\
\hline 4 & 39.3 & 38.7 & 37.5 & 36.8 & 38.6 & 37.4 & 36.3 & 37.3 & 36.3 \\
\hline 5 & 55.4 & 55.2 & 48.8 & 50.0 & 51.2 & 48.9 & 49.2 & 48.9 & 49.2 \\
\hline 6 & 18.3 & 18.3 & 18.2 & 17.3 & 18.2 & 18.3 & 18.1 & 18.3 & 18.1 \\
\hline 7 & 33.7 & 32.8 & 35.2 & 30.8 & 32.0 & 32.8 & 32.3 & 32.6 & 31.9 \\
\hline 8 & 43.6 & 40.0 & 43.5 & 42.2 & 40.7 & 40.2 & 40.2 & 40.1 & 40.0 \\
\hline 9 & 55.3 & 46.1 & 55.8 & 153.1 & 154.2 & 46.8 & 46.6 & 46.6 & 46.6 \\
\hline 10 & 38.1 & 36.8 & 38.2 & 37.5 & 37.9 & 36.9 & 36.8 & 36.9 & 36.8 \\
\hline 11 & $68.2^{\mathrm{a}}$ & 23.3 & $68.4^{\mathrm{a}}$ & 114.6 & 115.5 & 23.3 & 23.2 & 23.5 & 23.4 \\
\hline 12 & 129.2 & 125.1 & 128.7 & 122.2 & 123.0 & 125.2 & 125.3 & 122.4 & 122.6 \\
\hline 13 & 141.3 & 137.9 & 142.9 & 137.7 & 141.4 & 137.9 & 137.5 & 143.5 & 142.9 \\
\hline 14 & 44.3 & 44.0 & 42.2 & 41.8 & 43.1 & 44.2 & 43.9 & 43.9 & 43.7 \\
\hline 15 & 36.0 & 35.9 & 27.9 & 30.7 & 28.2 & 35.9 & 33.8 & 35.6 & 33.6 \\
\hline 16 & 66.7 & 67.0 & 27.7 & 69.9 & 26.1 & 67.0 & 70.8 & 66.1 & 69.8 \\
\hline 17 & 38.5 & 38.5 & 33.6 & 36.3 & 33.7 & 38.6 & 37.6 & 37.4 & 36.5 \\
\hline 18 & 59.9 & 60.7 & 58.1 & 57.8 & 57.3 & 60.8 & 60.8 & 49.1 & 49.9 \\
\hline 19 & $39.5^{\mathrm{c}}$ & 39.5 & 39.4 & $38.2^{\mathrm{c}}$ & 39.0 & 39.6 & 39.5 & 46.6 & 46.5 \\
\hline 20 & $39.1^{\mathrm{c}}$ & 39.4 & 39.3 & $37.5^{\mathrm{c}}$ & 39.5 & 39.5 & 39.4 & 30.9 & 30.8 \\
\hline 21 & 30.4 & 30.5 & 31.1 & 29.5 & 31.2 & 30.5 & 30.5 & 34.2 & 34.3 \\
\hline 22 & 35.2 & 35.2 & 41.3 & 34.4 & 41.4 & 35.2 & 35.4 & 30.6 & 30.8 \\
\hline 23 & 28.4 & 28.1 & 28.7 & 27.1 & 28.2 & 28.3 & 27.8 & 28.3 & 27.8 \\
\hline 24 & 15.7 & 15.6 & 22.4 & 15.7 & 17.4 & 22.3 & 22.6 & 22.3 & 22.6 \\
\hline 25 & 17.0 & 15.7 & 16.6 & 17.0 & 17.6 & 15.5 & 15.5 & 15.3 & 15.3 \\
\hline 26 & 18.0 & 16.8 & 18.0 & 21.7 & 22.2 & 16.9 & 16.8 & 16.9 & 16.8 \\
\hline 27 & 24.3 & 24.5 & 23.3 & 24.4 & 25.5 & 24.7 & 24.4 & 27.3 & 27.0 \\
\hline 28 & 21.9 & 21.9 & 28.6 & 22.2 & 28.7 & 21.9 & 21.4 & 21.5 & 21.9 \\
\hline 29 & 17.8 & 17.6 & 17.5 & 16.5 & 16.8 & 17.6 & 17.6 & 33.3 & 33.0 \\
\hline 30 & 21.5 & 21.3 & 21.3 & 21.2 & 21.5 & 21.3 & 21.3 & 23.9 & 23.8 \\
\hline \multicolumn{4}{|c|}{$\mathrm{MeCO}$} & 169.8 & 171.0 & & 170.9 & & 170.8 \\
\hline \multicolumn{4}{|c|}{$\mathrm{MeCO}$} & 170.0 & & & & & \\
\hline \multicolumn{4}{|c|}{$\underline{\mathrm{MeCO}}$} & 20.3 & 21.3 & & 21.2 & & 21.2 \\
\hline \multicolumn{4}{|c|}{$\mathrm{MeCO}$} & 20.3 & & & & & \\
\hline
\end{tabular}

Assignments based on HSQC, HMBC and G-NOESY for 4, HMBC for 4a and DEPT for 6a and 8a. In 4a: C-3 acetoxyl group $\delta$ 170.0; $\mathrm{C}-16$ acetoxyl group $\delta$ 169.8. The use of compound $\mathbf{1 3}$ as a model permitted to find out that Mahato and Kundu ${ }^{10}$ published the ${ }^{13} \mathrm{C}$ NMR data for $3 \beta$-hydroxyurs-9(11),12-diene, however, they were for $3 \beta$-acetoxyurs-9(11),12-diene (see reference 26 ); a The structural assignment was also supported by comparison of the ${ }^{13} \mathrm{C}$ NMR spectrum with those of olean derivatives, $11 \alpha$-methoxyolean-12-ene and $11 \beta$-hydroxyolean-12ene derivatives. ${ }^{27,28}$; ${ }^{b}$ Dehydration of 11-hydroxyolean-12-ene and 11-hydroxyurs-12-ene see reference 29 ; ${ }^{\mathrm{c}}$ Assignment interchangeable. 
proton signal at $\delta 5.46\left(\delta_{\mathrm{C}} 69.9\right)$ was confirmed to $\mathrm{H}-16$ and the ${ }^{13} \mathrm{C}$ signals at $\delta 169.8$ and 22.2 were attributed to C-16 acetoxyl group and C-28, respectively, due their correlations with the $\mathrm{H}-16$ signal. The ${ }^{1} \mathrm{H}$ NMR also showed an olefinic proton to be coupled to H-12 ( $\delta 5.49$, d, $J 5.6$ $\mathrm{Hz} ; 5.61 \mathrm{~d}, J 5.6 \mathrm{~Hz}$,), thus indicating the second double bond between C-9 and C-11. The olefinic proton signal at $\delta 5.49$ was attributed to $\mathrm{H}-12$ by its correlation with the C-18 ( $\delta$ 57.8) signal. H-12 signal also showed cross peaks with the ${ }^{13} \mathrm{C}$ signal at $\delta 41.8$ (quaternary carbon), which was attributed to $\mathrm{C}-14$. In the same way, the olefinic proton signal at $\delta 5.61$ to $\mathrm{H}-11$ emerged from the correlations between the $\mathrm{H}_{3}-25$ and $\mathrm{H}-11$ signals with the ${ }^{13} \mathrm{C}$ signals at $\delta 37.5$, assigned to C-10. H-11 signal also showed cross peaks with the ${ }^{13} \mathrm{C}$ signal at $\delta 42.2$, which was attributed to C-8. Moreover, $\mathrm{H}_{3}-25$ showed cross peaks with the C-5 signal $(\delta 50.0)$ and the ${ }^{13} \mathrm{C}$ signals at $\delta 153.1$ and 35.9, leading to their assignments as C-9 and C-1, respectively. The signal for C-13 was established as 137.7 by the existence of a correlation between the $\mathrm{H}_{3}-27$ signal $(\delta 0.99)$ and this ${ }^{13} \mathrm{C}$ signal. $\mathrm{H}_{3}-27$ signal also showed cross peaks with the ${ }^{13} \mathrm{C}$ signals at $\delta 30.7$, which was attributed to C-15. The relationship of ${ }^{1} \mathrm{H}$ signal at $\delta 1.69(\mathrm{~d}, J 11.1 \mathrm{~Hz})$ to the $\mathrm{C}-13, \mathrm{C}-14, \mathrm{C}-17$ signals and the ${ }^{13} \mathrm{C}$ signal at $\delta$ 122.2 led to their assignments as $\mathrm{H}-18$ and $\mathrm{C}-12$. Thus, the second olefinic carbon at $\delta 114.6$ was attributed to C-11. The ursa-9(11),12-diene system was also supported by the ${ }^{13} \mathrm{C}$ NMR spectrum which agreed closely with published data for $3 \beta$-acetoxyurs-9(11), 12-diene (13). ${ }^{10}$ In the HMBC experiments several other long-range correlations were observed, which also confirmed the attribution of all the ${ }^{13} \mathrm{C}$ signals of the molecule (Table 3 and 4 ).

Compounds $3 \alpha, 16 \beta$-dihydroxyurs-12-ene (6) and $3 \alpha, 16 \beta$-dihydroxyolean-12-ene (8) have previously been isolated from Canarium album. ${ }^{7}$ In the present investigation the physical separation of these compounds was not achieved, even after acetylation with anhydride in pyridine, but the ${ }^{13} \mathrm{C}$ NMR data (Table 4) left no doubt that they were $3 \alpha, 16 \beta$-diacetoxy derivatives $6 \mathbf{a}$ and $8 \mathbf{a}$. The presence of urs- and olean-12-ene systems were indicated by the characteristic olefinic ${ }^{13} \mathrm{C}$ resonances at $\delta 125.3$ and $137.5,122.6$ and 142.9 , respectively. The latter ${ }^{13} \mathrm{C}$ signals were more intense than the former, indicating the olean-12-ene derivative as the major compound. In the same way, the intense olefinic ${ }^{1} \mathrm{H}$ signal at $\delta 5.26$ (t, $J 3.6$ $\mathrm{Hz}$ ) was then assigned to $\mathrm{H}-12$ of oelan-12-ene, whereas $\delta$ $5.20(\mathrm{t}, J 3.6 \mathrm{~Hz})$ to $\mathrm{H}-12$ of urs-12-ene derivative. The ${ }^{1} \mathrm{H}$ and ${ }^{13} \mathrm{C}$ NMR spectra revealed the presence of two acetoxyl groups. The identification of the A-ring containing only $3 \alpha$-acetoxyl group as substituent was supported by the coupling constants for H-3 $(\delta 4.63, \mathrm{t}, J 2.7 \mathrm{~Hz}, \mathbf{8 a}$; 4.50, t,
$J 2.7 \mathrm{~Hz}, 6 \mathbf{6})$ and ${ }^{13} \mathrm{C}$ NMR spectrum, which showed that the acetylation accentuated the $\alpha$-effect $(\mathrm{C}-3, \delta$ 78.1) and diminished the $\beta$-effect (C-2, $\delta$ 22.7; C-4, $\delta$ 36.3) when compared with published data for C-2 to C-4 in $\mathbf{6}$ and $\mathbf{8}$. Inspection of the ${ }^{13} \mathrm{C}$ NMR data of various hydroxy ursand olean-12-enes, revealed that introduction of a hydroxyl group only on D- and E-ring causes a significant alteration of the chemical shift of C-18 $(\delta 58.9,5 ; 60.8,6$; 47.4, 7; $49.1,8) .{ }^{10}$ Although, in urs- and olean-12-enes containing $21 \beta$-, 21 $\alpha$-, 22 $\alpha$ - and $22 \beta$-hydroxyl groups, the C-21 and $\mathrm{C}-22$ resonate at $\delta 70.0$ to $76.7 .^{10}$ In olen-12-enes containing $15 \alpha$ - or $16 \beta$-hydroxyl groups, these carbinyl carbons resonate at $\delta 65.9$ to $68.2{ }^{10}$ The coupling constants of ${ }^{1} \mathrm{H}$ signals of an oxymethine for $\mathbf{6 a}$ and $\mathbf{8 a}(\delta 5.46, \mathrm{dd}, J$ 11.9 and $5.0 \mathrm{~Hz}, \mathbf{8 a} ; 5.48$, dd, $J 11.9$ and $5.0 \mathrm{~Hz}, 6 \mathbf{a})$ indicated that the acetoxyl group would be attached equatorial to $\mathrm{C}-15(\alpha)$ or $\mathrm{C}-16(\beta)$, thus the above compounds are excellent models. The presence of a hydroxyl group at C-15 $\alpha$ has a pronounced effect on the olefinic carbon resonances. The chemical shift of C-12 and $\mathrm{C}$-13 in 3 $\beta, 15 \alpha$-dihydroxyolean-12-ene appear at $\delta$ 123.0 and 146.1 , respectively. The corresponding resonances for $3 \beta, 16 \beta$-dihydroxyolean-12-ene appear at $\delta 122.2$ and 143.4 , i.e. C-13 is shielded by $\Delta \delta 2.7 .{ }^{10}$ The shielded resonance observed for $\mathbf{8 a}(\delta 122.6$ and 142.9) is typical of $16 \beta$-hydroxyolean-12-ene, determining the position of the second acetoxyl group at C-16 $\beta$. Although, no urs-12-ene containing a $15 \alpha$-hydroxyl group appears to have been isolated so far. However, for the analogous structural situation in 3 $\beta$-hydroxyoelan-12-en-27,28-dioic $(\mathrm{C}-13, \delta$ 138.1) and 3 $\beta$-hydroxyurs-en-27,28-dioic (C-13, $\delta$ 134.2) acids a similar shield is observed for C-13 in both systems $[\mathrm{C}-13, \delta 145.1(\mathbf{7})-138.1=\Delta \delta 7.0 ; \delta 139.3(\mathbf{5})$ $-134.2=\Delta \delta 5.1] .{ }^{10}$ Placement of the acetoxyl group at $\mathrm{C}$ 16 received further support from acetylation of $\mathbf{4}$, which yielded 4a. In the ${ }^{13} \mathrm{C}$ NMR spectrum of $4 \mathbf{a}$ (Table 4) the signal for C-16 was observed at $\delta 69.9$, in close agreement with the resonance for the corresponding carbon in $\mathbf{6 a}(\delta$ $70.8)$ and $\mathbf{8 a}(\delta 69.8)$. All the above data suggested that $\mathbf{6 a}$ was $3 \alpha, 16 \beta$-diacetoxyurs-12-ene and $8 \mathbf{a}$ was $3 \alpha, 16 \beta$ diacetoxyolean-12-ene.

The ${ }^{1} \mathrm{H}$ NMR spectra of concentrated $\mathrm{MeOH}$ extracts of stem bark of $T$. burserifolia, branch and resin of $T$. rhoifolia, branch and resin of Dacryodes hopkinsii showed signals corresponding to triterpenes isolated from resin of T. burserifolia. Thus, only $\mathrm{CH}_{2} \mathrm{Cl}_{2}$-soluble fractions of these extracts were further examined by their ${ }^{13} \mathrm{C}$ NMR spectra which showed that the major triterpenes were in stem bark of T. burserifolia $\alpha$-amyrin (5) and $\beta$-amyrin (7); in branch of T. rhoifolia $\alpha$-amyrin (5), $\beta$-amyrin (7), 3-epi$\alpha$-amyrin, 3-epi- $\beta$-amyrin, lupenone ${ }^{11}$ and sitosterol; in 
resin of T. rhoifolia $\alpha$-amyrin (5), $\beta$-amyrin (7), 3-epi- $\alpha$ amyrin, 3-epi- $\beta$-amyrin, $3 \alpha$-hydroxytirucall-8,24-dien-21oic acid ${ }^{8}$ and $3 \alpha$-hydroxytirucall-7,24-dien-21-oic acid; ${ }^{6}$ in branch of $D$. hopkinsii $\alpha$-amyrin (5), $\beta$-amyrin (7), lupeol, ${ }^{10}$ tirucallol, ${ }^{12}$ sitosterol and stigmasterol; and in resin of $D$. hopkinsii $\alpha$-amyrin (5) and $\beta$-amyrin (7).

\section{Chemosystematic implications}

Burseraceous genera are characterised by the production of tetracyclic tirucallane, dammarane, cycloartane, lanostane, and pentacyclic lupane, ursane and oleanane triterpenes. ${ }^{13}$ Ursanes and/or oleananes are omnipresent. All genera produce volatile oils which are often represented by many different sesquiterpenes, aromadendranes, humulanes, germacranes, eudesmanes, elemanes, guaianes, pseudo-guaianes, bourbonanes, caryophyllanes, cubebanes, cadinanes, copaanes and bisabolanes. ${ }^{13}$ Furosesquiterpenes have been isolated from Commiphora species. ${ }^{13}$ Lignans are less common and were for long known only from Bursera, but have now been recorded in Commiphora and Protium. ${ }^{14,15}$

Until recently the phytochemical knowledge of Protieae were the records of three dammaranes (dammaradienol in Garuga pinnata, ${ }^{16} 3 \alpha, 20$ (S)-dihydroxydammar-24-ene in Crepidospermum rhoifolium, ${ }^{5}$ and cabraleadiol in Protium apiculatum $^{5}$ ), one tirucallane (butirospermol in $G$. pinnata $\left.^{16}\right)$, two ursanes $(\alpha$-amirin and 3-epi- $\alpha$-amirin in $G$. pinnata ${ }^{16}$ and only the former in P. paniculatum $\mathrm{Engl}^{17}$ and P. icicariba $\left.^{5}\right)$, one oleanane $\left(\beta\right.$-amirin in P. paniculatum ${ }^{17}$ and $P$. icicariba ${ }^{5}$ ), one cycloartane (3 $\beta, 24$-dihydroxycycloart-25-ene in $C$. rhoifolium $^{5}$ ), one multiflorane (secoisobryononic acid in Tetragastris altissima ${ }^{5}$ ), one friedelane (friedelin in T. altissima ${ }^{5}$ ), one taraxerane (taraxerol in T. altissima ${ }^{5}$ ), one lupane (lupeol in P. icicariba ${ }^{5}$ and $P$. apiculatum $^{5}$ ), four sterols (sitosterol, stigmasterol, campesterol and $3 \beta$-O- $\beta$-D-glucopyranosylsitosterol in $C$. rhoifolium ${ }^{5}$, only the two first in P. paniculatum $;{ }^{17}$ and only the former in P. opacum Swart, ${ }^{18}$ P. apiculatum ${ }^{5}$ and $T$. altissima $)^{5}$, four lignans [(+)-(2S,3S)-2-(3', 4' methylenedioxy-acetophenone)-butyrolactone, (-)-cubebin epimers in P. tenuifolium Engl ${ }_{15}^{15}$ parabenzolactone in $C$. rhoifolium $^{5}$ and (-)-savinin in T. altissima $a^{5}$, one coumarin (propacin in $P$. opacum $^{18}$ ), one biflavonoid (amentoflavone in $G$. pinnata ${ }^{19}$ ) and two macrocyclic biphenyl ether (garuganin I and III in G. pinnata ${ }^{16}$ ). Protieae genera have been shown to have a chemical profile that is comparable to those of all other burseraceous tribes. ${ }^{5,13}$

All the burseraceous tribes yielded tirucallanes, ursanes, oleananes and lupanes, while dammaranes appear to have been recorded only from Protieae and Boswellieae genera. ${ }^{5}$ Trattinnickia has in common tirucallane, ursane and oleanane types with Dacryodes. Lupanes have been found only in Dacryodes. Furthermore, Dacryodes contains peculiar 3,4-secolupanes ${ }^{13}$ which could be taken as indicative of an affinity to the Boswellieae where similar lupanes occur. ${ }^{13}$ It is also chemical evidence favouring its classification in the Canarieae, notably by the cooccurrence of 3,4-secolupanes in Canarium muelleri and C. zeylanicum. ${ }^{13}$

The co-occurrence of dammaranes in Trattinnickia, Garuga ${ }_{17}$ Crepidospermum, $^{5}$ Protium ${ }^{5}$ and Commiphora ${ }^{20,21}$ suggests some affinity between Protieae and Boswellieae (Bursereae). The simplest dammaranes, in which the side chain is undegraded (as in dammarenediol-II and $3 \alpha, 20$ (S)dihydroxydammar-24-ene from T. burserifolia), are typical of the Protieae and that increasing ability to lose the entire C-17 side chain (as in mansumbinane ${ }^{21}$ ) occurs through the Boswellieae (in Commiphora). This can be seen as a further advance in oxidative mechanisms and appears to agree closely with the suggested phylogenetic sequence within the Burseraceae; Protieae considered the most primitive, Boswellieae intermediate. Thus, the isolation of two undegraded dammaranes from T. burserifolia suggest that Trattinnickia appears to have a less pronounced relationship to the Canarieae than to the Protieae, since they do not occur, at present, in the former. Thus, the presence of dammaranes in T. burserifolia does not support Daly's taxonomic conclusions. ${ }^{5}$

The most common tetracyclic triterpenes in the Rutales families are tirucall-7-en derivatives which are the precursors of the limonoids and quassinoids that are major chemotaxonomic characters of the order. ${ }^{22,23}$ The Burseraceae is an exception, no quassinoids or limonoids have so far been isolated. Burseraceous genera have heretofore yielded relatively few variety of compounds. This fact can be rationalised by the presence in their species of massive quantities of tannins (possibly also essential oils), general defences which make the presence of specific alleochemics superfluous. ${ }^{24}$ Essential oils represented by many different sesquiterpenes, appear to inhibit the formation of squalene, potential precursor of limonoids. ${ }^{25}$

\section{Experimental}

\section{General}

NMR on a Bruker DRX 400, with TMS as internal standard; ESI-MSMS: low resolution on a triple quadrupole Micromass Quattro LC instrument, equipped with a "Z-spray" ion source; GC-MS: Shimadzu GC-17A gas chromatograph fitted with a fused silica DB-5 (30 m x 
$0.25 \mathrm{~mm}$ ID, $0.25 \mu \mathrm{m}$ film thickness) capillary column with helium as the carrier gas at a flow rate of $1.6 \mathrm{~mL} \mathrm{~min}^{-1}$. The temperature was programmed initially at $60{ }^{\circ} \mathrm{C}$ for 2 $\mathrm{min}$, then increased with a rate of $3{ }^{\circ} \mathrm{C} \mathrm{min}^{-1}$ to $240{ }^{\circ} \mathrm{C}$. The injection was split and its temperature was $225^{\circ} \mathrm{C}$. The interface temperature was $250^{\circ} \mathrm{C}$. The chromatograph was coupled to a Shimadzu QP5000 mass selective detector at $70 \mathrm{eV}$; IR (BOMEN - Ft/IR). [ $\alpha]_{\mathrm{D}}$ : Perkin Elmer 241 instrument; IR (KBr, BOMEN - Ft/IR); R-HPLC: Recycling High-Performance Liquid Chromatography on a model Shimadzu LC-6AD; the column used was a Shim-pack Prep-Sil (H), 250 mm X 20 mm, 5 mm particle size, $100 \AA$ pore diameter; eluant: $\mathrm{CHCl}_{3}$; flow rate: $8.0 \mathrm{~mL} \mathrm{~min}^{-1}$ and $5.0 \mathrm{~mL} \mathrm{~min}{ }^{-1}$; detection (Shimadzu SPD-6AV): UV $\lambda 254 \mathrm{~nm}$.

\section{Plant material}

Trattinnickia burserifolia, T. rhoifolia and Dacryodes hopkinsii were collected from Forest Reserve Adolpho Ducke, Amazonas, Brazil; vouchers (184.962, 178.219, 178.240, respectively) were deposited in the Herbarium of Instituto Nacional de Pesquisa da Amazônia (INPA), Manaus, AM.

\section{Extraction and isolation from resin of T. burserifolia}

The resin was dissolved in $\mathrm{CHCl}_{3}$, filtered and concentrated under vacuum. The concentrated (60 g) was partitioned into $\mathrm{CHCl}_{3}, \mathrm{MeOH}$ and $\mathrm{H}_{2} \mathrm{O}$ soluble fractions. The concentrated $\mathrm{CHCl}_{3}$-soluble fraction was subjected to column chromatography over silica gel. Elution with a hexane- $\mathrm{CH}_{2} \mathrm{Cl}_{2}-\mathrm{MeOH}$ gradient afforded 6 fractions (3 hexane-fractions, 1 hexane $/ \mathrm{CH}_{2} \mathrm{Cl}_{2}$ fraction, $1 \mathrm{CH}_{2} \mathrm{Cl}_{2}$ fraction and $1 \mathrm{MeOH}$ fraction). The hexane fractions were combined in 2 groups on the basis of analytical TLC. The hexane-fraction 2-3 gave a mixture (12.6 g) of $\alpha$-amyrin (5) and $\beta$-amyrin (7). The hexane-fraction 1 was subjected to column chromatography over silica gel eluting with a hexane-EtOAc gradient to afford a mixture of 5 and 7 (3 g) and fractions A, B and C. Fraction A was twice flash chromatographed on silica gel, eluting with hexane-EtOAc gradient and finally with hexane-EtOAc (98:2) affording impure 1. Compound 1 was purified by R-HPLC $\left(\mathrm{CHCl}_{3}\right.$; detection UV $\lambda 254 \mathrm{~nm}$, flow rate: $8.0 \mathrm{~mL} \mathrm{~min}^{-1}$; see above) affording pure 1 at 1 first peak $(2.4 \mathrm{mg})$. Fraction B was flash chromatographed on silica gel, eluting with hexaneEtOAc gradient yielding 32 fractions. These fractions were combined in 5 groups on the basis of analytical TLC. The 5 groups were monitored by ${ }^{1} \mathrm{H}$ NMR (200 MHz) and were examined only those which showed features of taxonomic interest. Group 2 (fractions B17-24) was twice flash chromatographed on silica gel, eluting with benzene$\mathrm{CH}_{2} \mathrm{Cl}_{2}$ (9:1) and finally with hexane-EtOAc 95:5 affording a mixture (5 mg) of 2 and 3. Group 3 (fractions B25-27) was flash rechromatographed on silica gel eluting with hexane-EtOAc 95:5 yielding an amorphous solid which was purified by preparative TLC (silica gel; hexane$\mathrm{CH}_{2} \mathrm{Cl}_{2}$-THF, 10:1.0:0.25) to yield a mixture (7.9 mg) of $\alpha$ and $\beta$-amyrenone. Group 4 (fraction B28) was purified three times by preparative TLC (silica gel; benzene) to yield 3epi- $\alpha$-amyrin (8.4 mg). Group 5 (fractions B29-32) was flash rechromatographed on silica gel eluting with hexaneEtOAc 9:1 yielding 3-epi- $\beta$-amyrin (13 mg) after crystallization in hexane. Fraction $\mathrm{C}$ yielded a precipitate (458 mg) from which $80 \mathrm{mg}$ were methylated with $\mathrm{CH}_{2} \mathrm{~N}_{2}$ yielding the corresponding methyl ester of $3 \alpha$ hydroxytirucall-8,24-dien-21-oic acid.

Hexane $/ \mathrm{CH}_{2} \mathrm{Cl}_{2}$ fraction from the concentrated $\mathrm{CHCl}_{3}$ soluble fraction of resin was subjected to column chromatography over silica gel eluting with a hexane-EtOAc gradient to afford 42 fractions. These fractions were combined in 7 groups on the basis of analytical TLC. The 7 groups were monitored by ${ }^{1} \mathrm{H}$ NMR $(200 \mathrm{MHz})$ and were examined only those which showed features of taxonomic interest. Group 3 (fractions G3D17-19) yielded a precipitate which was dissolved in $\mathrm{Me}_{2} \mathrm{CO}$ and kept in the refrigerator overnight. The residue was flash rechromatographed on silica gel eluting with hexane- $\mathrm{CH}_{2} \mathrm{Cl}_{2}-\mathrm{MeOH}$ 20:5:1 yielding a mixture of $3 \alpha$-hydroxytirucall-8,24-dien-21-oic acid and $3 \alpha$-hydroxytirucall-7,24-dien-21-oic acid. The filtrate was evaporated and the residue was rechromatographed as above affording a mixture (160 mg) of $\alpha$-amyrin (5) and $\beta$-amyrin (7) and $3 \alpha$-hydroxytirucall-8,24-dien-21-oic acid (6.7 mg). Group 5 (fractions G5E28-37) was twice flash chromatographed on silica gel, eluting with hexane- $\mathrm{CH}_{2} \mathrm{Cl}_{2}-\mathrm{MeOH}$ 10:1:1 and finally with hexane-EtOAc (8:2) affording fraction G5E-X and 3-oxotirucall-8,24-dien-21-oic acid (16 $\mathrm{mg}$ ) after crystallisation in hexane- $\mathrm{Me}_{2} \mathrm{CO}$. Fraction $\mathrm{G} 5 \mathrm{E}-\mathrm{X}$ was acetylated with $\mathrm{Ac}_{2} \mathrm{O}$-pyridine to give acetate derivatives which were subsequently purified by flash chromatography eluting with hexane- $\mathrm{Me}_{2} \mathrm{CO}$ 8:2 affording fraction G5E-Xa and fraction G5E-Xb. Fraction G5E-Xa was flash rechromatographed on silica gel eluting with benzeneEtOAc 95:5 to yield a mixture (102 mg) of $\mathbf{6 a}$ and 8a. Fraction G5E-Xb was rechromatographed as above to afford a mixture (4.4 mg) of C3-epimers 3-acetoxyldammarenediolII and $3 \alpha$-acetoxy-20(S)-hydroxydammar-24-ene.

The $\mathrm{MeOH}$ fraction from the concentrated $\mathrm{CHCl}_{3}$ soluble fraction of resin was subjected to column chromatography over silica gel eluting with a hexaneEtOAc-MeOH gradient to afford 15 fractions. These 
fractions were combined in 7 groups on the basis of analytical TLC. The 7 groups were monitored by ${ }^{1} \mathrm{H}$ NMR (200 MHz) and were examined only those which showed features of taxonomic interest. Group 4 (fractions G4F5-8) was three times flash rechromatographed on silica gel eluting with $\mathrm{CH}_{2} \mathrm{Cl}_{2}$-EtOAc 7:3, then $\mathrm{CH}_{2} \mathrm{Cl}_{2}$-EtOAc 7:3 and finally $\mathrm{CH}_{2} \mathrm{Cl}_{2}-\mathrm{MeOH}$ 95:5, affording 4 (2.6 mg). Compound $\mathbf{4}$ was allowed to react overnight with an excess of $\mathrm{Ac}_{2} \mathrm{O}$ in pyridine. Work-up as usual yielded $3 \beta, 16 \beta$ diacetoxyurs-9(11),12-diene (4a).

Extractions from stem bark of Trattinnickia burserifolia, branch of $T$. rhoifolia, resin of $T$. rhoifolia, branch of Dacryodes hopkinsii and resin of D. hopkinsii

These organs ground were extracted with $\mathrm{MeOH}$. The ${ }^{1} \mathrm{H}$ NMR spectra of concentrated $\mathrm{MeOH}$ extracts showed signals corresponding to triterpenes isolated from resin above. They were partitioned into hexane, $\mathrm{CH}_{2} \mathrm{Cl}_{2}$ and $\mathrm{MeOH}$ soluble fractions. The ${ }^{1} \mathrm{H}$ NMR spectra of these fractions showed that the major triterpenes were in concentrated $\mathrm{CH}_{2} \mathrm{Cl}_{2}$-soluble fraction. The ${ }^{13} \mathrm{C} \mathrm{NMR}$ spectra of these fractions showed that the major triterpenes were in: a) stem bark of T. burserifolia, $\alpha$-amyrin (5) and $\beta$-amyrin (7); b) branch of T. rhoifolia, $\alpha$-amyrin (5), $\beta$-amyrin (7), 3epi- $\alpha$-amyrin, 3-epi- $\beta$-amyrin, lupenone and sitosterol; c) resin of T. rhoifolia, $\alpha$-amyrin (5), $\beta$-amyrin (7), 3-epi- $\alpha$ amyrin, 3-epi- $\beta$-amyrin, $3 \alpha$-hydroxytirucall-8,24-dien-21oic acid and $3 \alpha$-hydroxytirucall-7,24-dien-21-oic acid; d) branch of Dacryodes hopkinsii, $\alpha$-amyrin (5), $\beta$-amyrin (7), lupeol, tirucallol, sitosterol and stigmasterol; e) resin of $D$. hopkinsii, $\alpha$-amyrin (5) and $\beta$-amyrin (7).

\section{2( $\left(S^{*}\right)$-Phenylacetoxy-4( $\left.R^{*}\right)$-p-mentha-1(7),5-dien (1)}

Amorphous solid; $[\alpha]_{\mathrm{D}}{ }^{26}+2.5^{\circ}\left(\mathrm{CHCl}_{3} ; \mathrm{c} 0.0024\right)$; IR $v_{\max } / \mathrm{cm}^{-1}: 2956,2923,2851$ (aliphatic $\mathrm{CH}$ ), 1733 (ester), 1457 (aromatic C=C), (liq. film); ${ }^{1} \mathrm{H}$ NMR $(400 \mathrm{MHz}$, $\left.\mathrm{CDCl}_{3}\right)$ : see Table $1 ;{ }^{13} \mathrm{C}$ NMR $\left(100 \mathrm{MHz}, \mathrm{CDCl}_{3}\right.$, multiplicities assigned from DEPT 135 experiment): see Table 1; HMBC and HSQC (400/100 MHz, $\left.\mathrm{CDCl}_{3}\right)$ : see discussion. GC-MS: $R_{t} 22.27$, EIMS: $m / z$ (rel. int.): 1 failed to give an $[\mathrm{M}]^{+*}$, the main fragments observed being 150 for $\left[\mathrm{M}-\mathrm{C}_{6} \mathrm{H}_{5} \mathrm{CH}_{2} \mathrm{CO}-\mathrm{H}\right]^{+*}(10), 149$ for $[150-\mathrm{H}]^{+}(100)$, 119 for $\left[\mathrm{C}_{6} \mathrm{H}_{5} \mathrm{CH}_{2} \mathrm{CO}\right]^{+}(10), 91$ for $\left[\mathrm{C}_{6} \mathrm{H}_{5} \mathrm{CH}_{2}\right]^{+}(20)$.

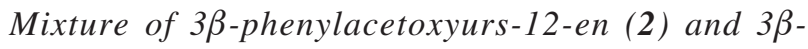
phenylacetoxyolean-12-en (3)

Amorphous solid; IR $v_{\max } / \mathrm{cm}^{-1}: 2937,2857$ (aliphatic $\mathrm{CH}$ ), 1733 (ester), 1455 (aromatic $\mathrm{C}=\mathrm{C}$ ), (liq. film); ${ }^{1} \mathrm{H}$ NMR $\left(400 \mathrm{MHz}, \mathrm{CDCl}_{3}\right): \delta 5.16(1 \mathrm{H}, \mathrm{t}, J 3.6 \mathrm{~Hz}, \mathrm{H}-12,3) ; 5.11$ $(1 \mathrm{H}, \mathrm{t}, J 3.6 \mathrm{~Hz}, \mathrm{H}-12,2), 4.48$ (1H, dd, J 11.0, $5.1 \mathrm{~Hz}, \mathrm{H}-3)$; 3.60 (2H, s, H-7'); 1.11-0.76 (16 Me, s). ${ }^{13} \mathrm{C}$ NMR (100 $\mathrm{MHz}, \mathrm{CDCl}_{3}$, multiplicities assigned from DEPT 135 experiment): see Table 2. GC-MS: R: $54.6 \mathrm{~min}$. and 54.13 min. EIMS: $m / z$ (rel. int.): $544[\mathrm{M}]^{+\bullet}(5), 218$ (100): associated with retro-Diels-Alder cleavage of C-ring, 119 for $\left[\mathrm{C}_{6} \mathrm{H}_{5} \mathrm{CH}_{2} \mathrm{CO}\right]^{+}(20), 91$ for $\left[\mathrm{C}_{6} \mathrm{H}_{5} \mathrm{CH}_{2}\right]^{+}(60)$.

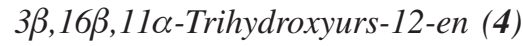

Amorphous solid; $[\alpha]_{\mathrm{D}}{ }^{24}+13.5^{\circ}\left(\mathrm{CHCl}_{3} ; \mathrm{c} 0.002\right)$; IR $v_{\max } / \mathrm{cm}^{-1} 3424(\mathrm{OH}), 2928,2867$ (aliphatic $\mathrm{CH}$ ), 1710 (ester), (liq. film); ${ }^{1} \mathrm{H} \mathrm{NMR}$ (400 MHz, $\mathrm{CDCl}_{3}$; resonances were confirmed by HSQC and HMBC experiments): $\delta 5.24$ $(1 \mathrm{H}, \mathrm{d}, J 3.2 \mathrm{~Hz}, \mathrm{H}-12), 4.27$ (1H, dd, J 8.7, $3.2 \mathrm{~Hz}, \mathrm{H}-11)$, $4.23(1 \mathrm{H}, \mathrm{dd}, J 11.1,5.2 \mathrm{~Hz}, \mathrm{H}-16), 3.23$ (1H, dd, $J 10.4,5.8$ $\mathrm{Hz}, \mathrm{H}-3), 2.20$ (2H, dt, $\left.J 13.5,3.4 \mathrm{~Hz}, \mathrm{H}_{2}-1\right), 2.03$ (2H, dt, $J$ 13.9, $\left.3.1 \mathrm{~Hz}, \mathrm{H}_{2}-7\right), 1.65\left(2 \mathrm{H}, \mathrm{m}, \mathrm{H}_{2}-2\right), 1.62\left(2 \mathrm{H}, \mathrm{m}, \mathrm{H}_{2}-22\right)$, $1.59(1 \mathrm{H}, \mathrm{m}, \mathrm{H}-6 \mathrm{a}), 1.57(1 \mathrm{H}, \mathrm{d}, J 11.3, \mathrm{H}-18), 1.48(1 \mathrm{H}, \mathrm{d}$, $J$ 8.7, H-9), 1.42 (2H, m, $\left.\mathrm{H}_{2}-21\right), 1.38$ (1H, m, H-6b), 1.36 $\left(2 \mathrm{H}, \mathrm{m}, \mathrm{H}_{2}-15\right), 1.20$ (3H, s, Me-27), 1.06 (3H, s, Me-25), 1.05 (3H, s, Me-26), 0.97 (3H, s, Me-23), 0.91 (3H, d, J 5.9 $\mathrm{Hz}, \mathrm{Me}-30), 0.82$ (3H, d, J6.3 Hz, Me-29), 0.77 (3H, s, Me24), 0.73 (3H, s, Me-28), 0.72 (1H, m, H-5). ${ }^{13} \mathrm{C}$ NMR (100 $\mathrm{MHz}, \mathrm{CDCl}_{3}$, multiplicities assigned from DEPT 135 experiment): see Table 4. ESI-MSMS (probe) $25 \mathrm{eV}, \mathrm{m} / \mathrm{z}$ (rel. int.): $457\left[\mathrm{M}-\mathrm{H}^{-}(100), 439\left[\mathrm{M}-\mathrm{H}-\mathrm{H}_{2} \mathrm{O}\right]^{-}\right.$(40), 421 $\left[\mathrm{M}-\mathrm{H}-\mathrm{H}_{2} \mathrm{O}-\mathrm{H}_{2} \mathrm{O}\right]^{-}(10), 247$ (30).

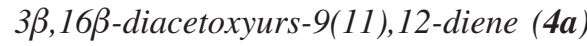

Amorphous solid; ${ }^{1} \mathrm{H}$ NMR (400 $\mathrm{MHz}, \mathrm{CDCl}_{3}$; resonances were confirmed by HMBC experiments): $\delta 5.61$ $(1 \mathrm{H}, \mathrm{d}, J 5.6 \mathrm{~Hz}, \mathrm{H}-11), 5.49$ (1H, d, J $5.6 \mathrm{~Hz}, \mathrm{H}-12), 5.46$ $(1 \mathrm{H}, \mathrm{dd}, J 11.4$ and $5.5 \mathrm{~Hz}, \mathrm{H}-16), 4.51(1 \mathrm{H}, \mathrm{dd}, J 11.4$ and $4.9 \mathrm{~Hz}, \mathrm{H}-3), 2.06$ (3H, s, MeCO), 2.05 (3H, s, MeCO), 1.69 $(1 \mathrm{H}, \mathrm{d}, J 11.1 \mathrm{~Hz}, \mathrm{H}-18), 1.23$ (3H, s, Me-25), 1.20 (3H, s, Me-26), 0.99 (3H, s, Me-27), 0.95 (3H, d, J 4.6 Hz, Me-30), 0.91 (3H, s, Me-28), 0.90 (3H, s, Me-23), 0.88 (3H, s, Me24), 0.81 (3H, d, $J 6.5 \mathrm{~Hz}, \mathrm{Me}-29) .{ }^{13} \mathrm{C}$ NMR (100 MHz, $\mathrm{CDCl}_{3}$ ): see Table 4 .

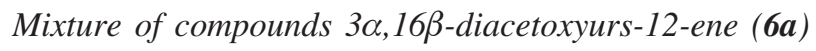
and $3 \alpha, 16 \beta$-diacetoxyolean-12-ene ( $8 a)$

${ }^{1} \mathrm{H}$ NMR $\left(400 \mathrm{MHz}, \mathrm{CDCl}_{3}\right): \delta 5.20(1 \mathrm{H}, \mathrm{t}, J 3.6 \mathrm{~Hz}, \mathrm{H}-$ $12, \mathbf{6 a}), 5.26(1 \mathrm{H}, \mathrm{t}, J 3.6 \mathrm{~Hz}, \mathrm{H}-12,8 \mathbf{a}), 5.46(1 \mathrm{H}, \mathrm{dd}, J 11.9$ and 5.0, H-16, 8a), $5.48(1 \mathrm{H}, \mathrm{dd}, J 11.9$ and 5.0, H-16, 6a), $4.63(1 \mathrm{H}, \mathrm{t}, J 2.7 \mathrm{~Hz}, \mathrm{H}-3,8 \mathrm{a}), 4.50(1 \mathrm{H}, \mathrm{t}, J 2.7 \mathrm{~Hz}, \mathrm{H}-3,6 \mathbf{6})$, $1.30-0.83(16 \mathrm{Me}) .{ }^{13} \mathrm{C}$ NMR $\left(100 \mathrm{MHz}, \mathrm{CDCl}_{3}\right)$ : see Table 4. 


\section{Acknowledgements}

The authors thank Conselho Nacional de Desenvolvimento Científico e Tecnológico (CNPq), Fundação de Amparo à Pesquisa do Estado de São Paulo (FAPESP), Coordenação de Aperfeiçoamento de Pessoal de Ensino Superior (CAPES), Financiadora de Estudos e Projetos (FINEP) for financial support.

\section{References}

1. Engler, A. von In Die Natürlichen Pflanzenfamilien; Engler, A.; von ; Prantl, K., eds., $2^{\text {nd }}$ ed., Engelmann: Leipzig, 1931, vol. 10, p.187.

2. Lam, H. J.; Bull. Jard. Bot. Buitenzorg III 1932, 12, 281.

3. Swart, J. J.; A Monograph of the Genus Protium and some Allied Genera (Burseraceae); Dukkerij Koch en Knuttel: Gouda, 1942.

4. Daly, D. C.; Britonia 1989, 41, 17.

5. Lima, M. da P.; Castro, F. B. G. de; Ferreira, A. G.; Rodrigues Fo, E.; Silva, M. F. das G. F. da; Fernandes, J. B.; Vieira, P. C.; Rev. Latinoamer. Quim. 2001, 29, 135.

6. Guang, L.; Gray, A. I.; Waterman, P. G.; Phytochemistry 1988, 27, 2283.

7. Tamai, M.; Watanabe, N.; Someya, M.; Kondoh, H.; Omura, S.; Ling, Z. P.; Chang, R.; Ming, C. W.; Planta Med. 1989, 55, 44.

8. Sawadogo, M.; Tessier, A. M. V.; Delaveu, P.; Ann. Pharm. Fr. 1985, 43, 89.

9. Matusch, R.; Schmidt, G.; Helv. Chim. Acta 1989, 72, 51.

10. Mahato, S. B.; Kundu, A. P.; Phytochemistry 1994, 37, 1517.

11. Wenkert, E.; Baddeley, G. V.; Burfitt, I. R.; Moreno L. N.; Org. Magn. Reson. 1978, 11, 337.

12. Polonsky, J.; Varon, Z.; Rabanal, R. M.; Jacquemin, H.; Isr. J. Chem. 1977, 16, 16.
13. Khalid, S. A. In Chemistry and Chemical Taxonomy of the Rutales; Waterman, P. G.; Grundon, M. F.; eds., Academic Press: New York, 1983, p. 281.

14. O'Sullivan, J. In Chemistry and Chemical Taxonomy of the Rutales; Waterman, P. G.; Grundon, M. F.; eds., Academic Press: New York, 1983, p. 267.

15. Siqueira, J. B. G.; Zoghbi, M. das G. B.; Cabral, J. A.; WolterFilho, W.; J. Nat. Prod. 1995, 58, 730.

16. Mishra, A. K.; Haribal, M. M.; Sabata, B. K.; Phytochemistry 1985, 24, 2463.

17. Zoghbi, M. das G. B.; Siqueira, J. B. G.; Wolter, E. L. A.; Júnior, O. L. P.; Acta Amazonica 1994, 24, 59.

18. Zoghbi, M. das G. B.; Roque, N. F.; Gottlieb, O. R.; Phytochemistry 1981, 20, 180.

19. Ansari, F. R.; Ansari, W. H.; Rahman, W.; Indian J. Chem., Sect. B 1978, 16B, 846.

20. Ampofo, S.; Waterman, P. G.; Phytochemistry 1985, 24, 2925.

21. Provan, G. J.; Waterman, P. G.; Phytochemistry 1986, $25,917$.

22. Silva, M.F. das G.F. da; Gottlieb, O.R.; Dreyer, D.L.; Biochem. Syst. Ecol. 1984, 12, 299.

23. Silva, M.F. das G.F. da; Gottlieb, O.R.; Biochem. Syst. Ecol. 1987, $15,85$.

24. Gottlieb. O. R.; J. Ethnopharmacol. 1982, 6, 227.

25. Kaplan, M. A. C.; Gottlieb. O. R.; Interciencia 1990, 15, 26.

26. Matsunaga, S.; Tanaka, R.; Akagi, M.; Phytochemistry 1988, 27, 535 .

27. Mathiasa, L.; Vieira, I. J. C.; Braz-Filho, R.; Rodrigues-Filho, E., J. Braz. Chem. Soc. 2000, 11, 195.

28. Barreiros, M. L.; David, J. M.; Pereira, P. A. P.; Guedes, M. L. S.; David, J. P.; J. Braz. Chem. Soc. 2002, 13, 669.

29. Barnes, R. A.; Pereira, A. L.; Scofield, C. V.; Braz-Filho, R.; Pinto, A. C. Chem. Pharm. Bull. 1984, 32, 3674.

Received: July 17, 2003

Published on the web: May 10, 2004

FAPESP helped in meeting the publication costs of this article. 